\title{
Analysis of the grain market in Ukraine in the context of land reform
}

\author{
Tetiana Rybachuk-Iarova, Iryna Tiukha
}

National University of Food Technologies, Kyiv, Ukraine

\begin{tabular}{|c|c|}
\hline & Abstract \\
\hline Keywords: & \multirow{22}{*}{ 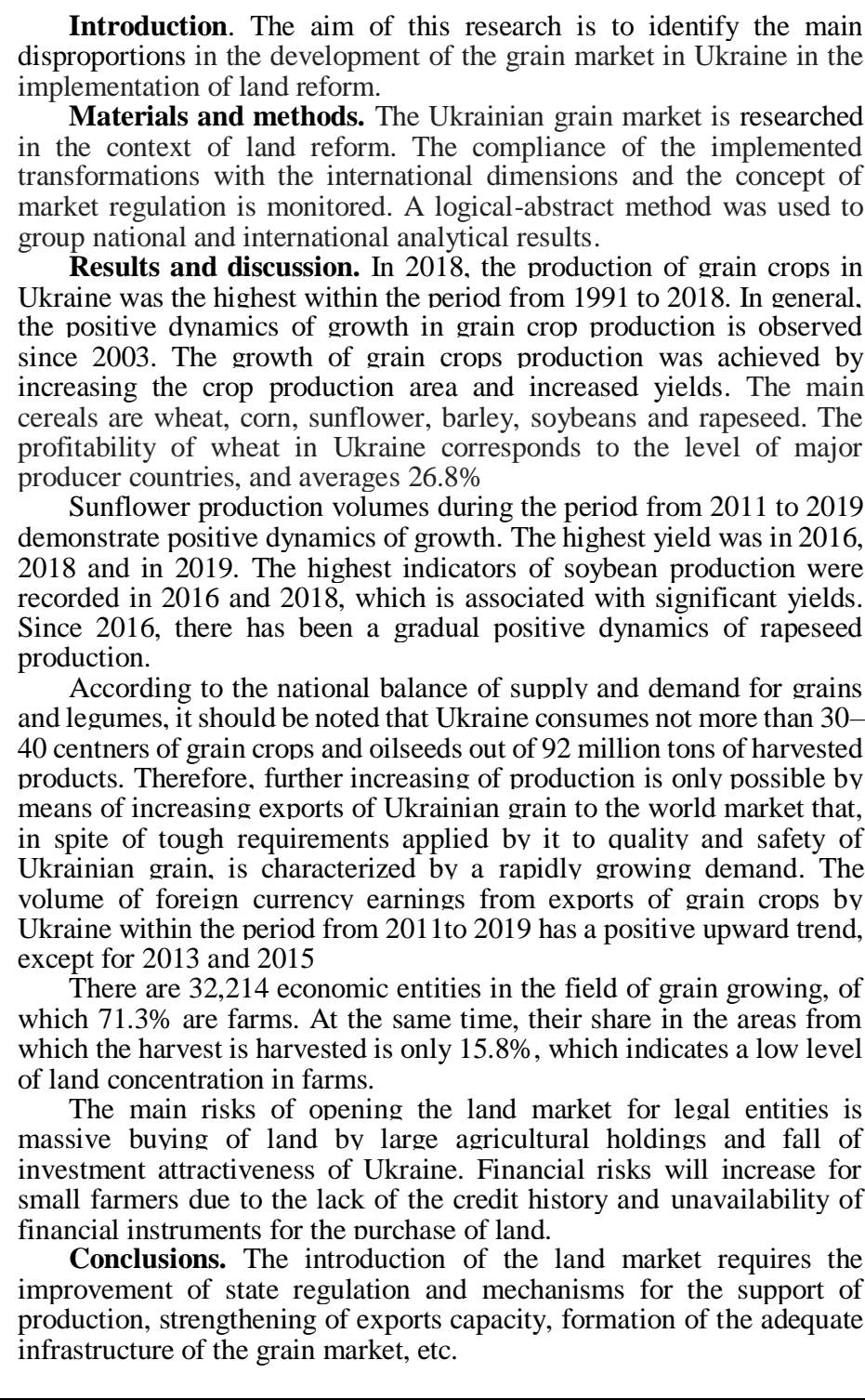 } \\
\hline & \\
\hline Production & \\
\hline Export & \\
\hline Ukraine & \\
\hline Reform & \\
\hline Article history: & \\
\hline Received & \\
\hline 22.10 .2019 & \\
\hline $\begin{array}{l}\text { Received in } \\
\text { revised form }\end{array}$ & \\
\hline 15.02 .2020 & \\
\hline Accepted & \\
\hline & \\
\hline $\begin{array}{l}\text { Corresponding } \\
\text { author: }\end{array}$ & \\
\hline Iryna Tiukha & \\
\hline E-mail: & \\
\hline & \\
\hline & \\
\hline & \\
\hline & \\
\hline & \\
\hline & \\
\hline
\end{tabular}




\section{Introduction}

The state of the country's grain market is an important indicator of the quality of economic reforms carried out in the country, the implementation of agri-food policy. As an object of state regulation, the grain market needs to identify its nature, mission, functions, role in the macroeconomic system of the country $[1,12,19]$.

Efficiency of developing the crop production industry influences welfare of population, ensures national food security and country's export capabilities [20]. The grain is the basis of all agricultural production that determines the volume of supply and the cost of food staples, forms a considerable part of the agricultural producers' income, determines the status and trends of development of rural areas, and generates foreign exchange earnings of the state $[12,17]$.

Market transformations of strategically important commodity markets, in particular, grain, are reflected in the works of many domestic and foreign scientists $[1,7,14,18,19]$. At the same time, the issues of grain production, foreign trade and internal distribution in the conditions of land market opening remain insufficiently covered and require further research $[10,11,19]$.

The above-mentioned conditioned consideration and critical analysis of the following tasks: the balance of supply and demand of grain in Ukraine in 2014/15 - 2018/19 marketing years $[5,6]$; the factors influencing the state of the grain market in Ukraine, in particular the dynamics of areas sown with cereals and legumes $[6,9,10]$, the volume and structure of grain production [6,9]; the structure of land depending on the type of owner [10]; the risks and opportunities of land reform for grain producers in Ukraine [11].

The purpose of the study is to identify problems in the functioning of the grain market of Ukraine in the implementation of land reform.

\section{Materials and methods}

\section{Materials}

The object of study is the grain market of Ukraine.

Subjects of research are: the crop production area planted with grain crops and grain legumes, the grain yield, the volume of grain crop production, the production of wheat, corn, sunflower, rape seeds and soybeans, the volume of foreign currency earnings from exports of grain crops by Ukraine, the countries leading in exporting wheat, the leading exporters of corn (Kernel, COFCO Agri Ukraine, ADM Trading Ukraine, Nibulon, Suntrad) and also risks and opportunities of land reform in Ukraine.

\section{Methods}

The methodology of the study included statistical analysis, grouping, systematization of indicators of grain market development. The logic of presentation of the material follows the structure of the national grain market. The logic of the study is subordinated to the task of analyzing the constituent parts of the national grain market.

It was used used official materials of the State Statistics Committee of Ukraine about the harvesting of grain crops: harvested areas [6], production [6,9], yielding capacity [6,20]; indicators of grain supply and demand in Ukraine $[6,14,15,16,18,20]$, volume of grain exports $[4-6 ; 12,13]$. 
In addition, we used research and analytical studies of domestic and foreign organizations of the countries that lead in exports of wheat and maize [1,7,12-14;18], and results of the rating evaluation of the leading exporters of grain [8-10].

\section{Results and discussion}

Grain production is a sector, products of which always was, is and will be one of the most important sources of wealth of any state. In the global agriculture, grain crops constantly dominated, and even today grain remains the most important and strategic agricultural product [9].

Grain is used by human beings in the form of bread, cereals, pasta, confectionery, etc. These products are distinguished by high nutritional and taste qualities, contain enough protein, carbohydrates, vitamins, amino acids, and minerals. Products of grain growing industry are raw materials for the processing industry. Alcohol, starch and other products can be obtained as the result of grain processing, pulp, paper, etc. can be produced as a result of straw processing. Grain is the main and indispensable forage in animal husbandry. It has a much higher nutritional value as compared with other types of feed, is characterized by a high content of forage units, digestible protein, macro- and micronutrients. By-products of grain growing — straw and chaff — and grain by-products are also used as forage.

The total demand for grain in the country is determined by the amount of grain consumed for nutrition, processing, forage, seeds, exports, and creation of state reserves. The largest share in this volume is occupied by grain that is consumed by human beings and animals as food/feed. In Ukraine, $52-57 \%$ of the total volume of produced grain crops are used as forage for livestock and poultry, $15-17 \%$ - as food, 8-10\% - as seeds, 3-4\% are processed and up to 6-8\% are lost during storage and post-harvesting [9].

It is quite natural, climatic conditions are favorable for cultivation of almost all the wellknown grains and legumes. As of 1 January 2020, 68.7 \% of Ukraine - almost 41.5 million hectares - are agriculturally used areas. In particular, 32.5 million hectares are arable lands. 1.7 million hectares out of 10.4 million hectares of agriculturally used areas owned by the state were transferred to united municipalities, while 1.6 million hectares are rented, 1.4 million hectares are reserve lands, 1.3 million hectares remain in constant use, 700 thousand hectares are located at the occupied territory. Within the period from 2013 to 2019, 630 thousand hectares were transferred to private ownership. And it is surprising that almost $30 \%$ - 3.1 million hectares are marked as the "statistical error".

\section{Balance of grain crops supply and demand in Ukraine}

In marketing year 2018/19, grain crop production in Ukraine was by 7.9 million tons higher than in marketing year 2017/18 and reached almost 70 million tons. Production of corn increased the most. Along with the growth of the gross production, volume of exports in the 2018/19 MY was at the level of 47.5 million tons that exceeds last year's level by 6.5 million tons. Forage consumption of grain crops increased by $11 \%$ or by 1.2 million tons again mainly due to corn [6].

The balance of grain crops supply and demand in Ukraine in marketing years 2014/152018/19 is shown in Table 1. 
Balance of grain crops supply and demand in Ukraine

Table 1 in marketing years 2014/15 to 2018/19 MP, thousand tons

\begin{tabular}{|l|c|c|c|c|c|}
\hline \multirow{2}{*}{\multicolumn{1}{c|}{ Indicator }} & \multicolumn{5}{c|}{ Years } \\
\cline { 2 - 6 } & $\mathbf{2 0 1 4 / 1 5}$ & $\mathbf{2 0 1 5 / 1 6}$ & $\mathbf{2 0 1 6 / 1 7}$ & $\mathbf{2 0 1 7 / 1 8}$ & $\mathbf{2 0 1 8 / 1 9}$ \\
\hline Initial reserves & 6831 & 8981 & 6044 & 6454 & 6305 \\
\hline Harvesting areas, ha & 14,627 & 14,641 & 14,337 & 14,560 & 14,782 \\
\hline $\begin{array}{l}\text { Crop capacity, } \\
\text { kg/centner }\end{array}$ & 4.4 & 4.1 & 4.6 & 4.3 & 4.7 \\
\hline Production & 63,859 & 60,126 & 66,088 & 61,917 & 69,800 \\
\hline Imports & 197 & 211 & 223 & 279 & 237 \\
\hline Aggregate supply & 70,888 & 69,318 & 72,355 & 68,649 & 76,342 \\
\hline Exports & 35,179 & 39,924 & 45,212 & 40,956 & 47,472 \\
\hline Forage consumption & 14,933 & 12,728 & 10,226 & 10,610 & 11,671 \\
\hline Food processing & 6208 & 5835 & 5685 & 5578 & 5392 \\
\hline Industrial consumption & 1294 & 1057 & 1258 & 1577 & 1142 \\
\hline Seeds & 2236 & 2325 & 2217 & 2221 & 2266 \\
\hline Losses & 2056 & 1405 & 1303 & 1403 & 1756 \\
\hline Domestic distribution & 61,906 & 63,273 & 65,901 & 62,344 & 69,789 \\
\hline Final stocks & 8981 & 6044 & 6454 & 6305 & 6554 \\
\hline \multicolumn{7}{|l|}{ Source: } & & & & \\
\hline
\end{tabular}

Source: [6]

As Table 1 shows, the overall supply of grain crops during marketing years 2014/152018/19 tended to increase from 70,888 thousand tons in the 2014/15 MY to 76,342 thousand tons in 2018/19 MY.

It should be noted that, with a slight increase in production areas, there was the growth in grain yield in 2014/15 MY from $4.4 \mathrm{~kg} / \mathrm{ha}$ to $4.7 \mathrm{~kg} / \mathrm{ha}$ in 2018/19 MY.

\section{Crop production area planted with grain crops and grain legumes}

The dynamics of the areas planted with grain crops and grain legumes within the period from 1991 to 2018 is shown in Figure 1.

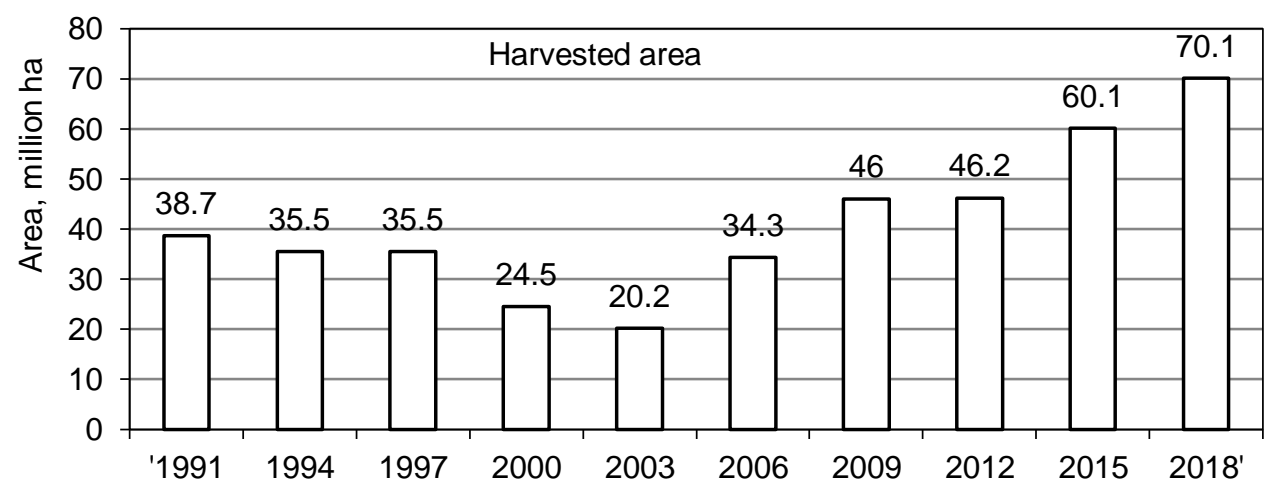

Figure 1. Dynamics of the area planted with grain crops and grain legumes within the period from 1991 to 2018, million ha [6]. 
Thus, the crop production area planted with grain crops and grain legumes remained almost unchanged over the period from 1991 to 2018.

\section{Volume of grain crop production} to 2018 .

The figure illustrates the volume of grain crop production within the period from 1991

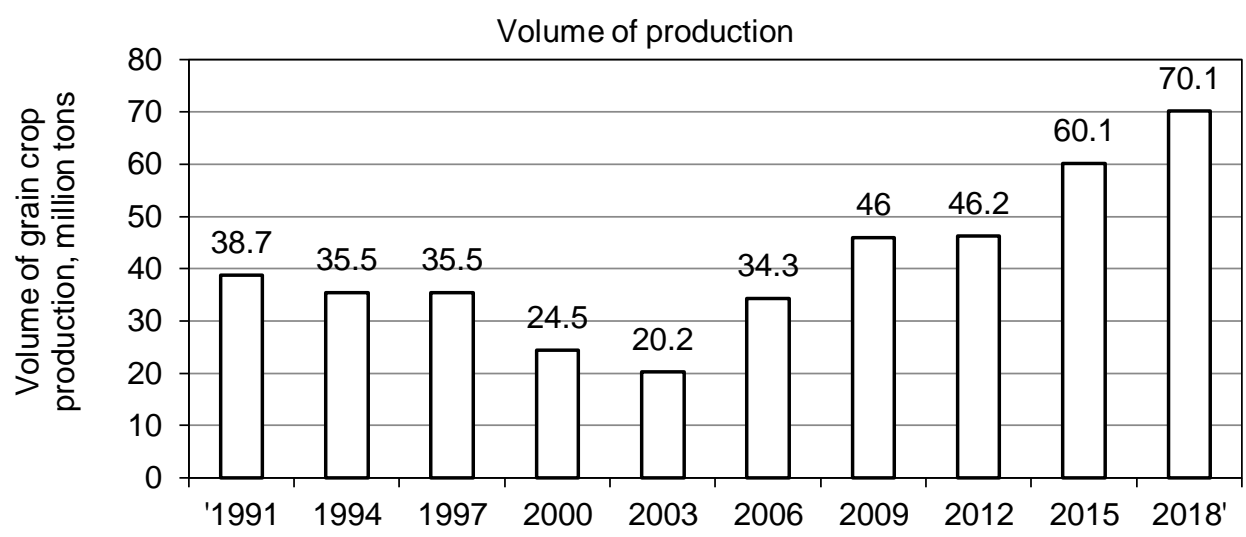

Figure 2. Volume of grain crop production within the period from 1991 to 2018 in Ukraine, million tons [6]

As Figure 2 shows, In 2018, the production of grain crops in Ukraine was the highest within the period from 1991 to 2018. In general, the positive dynamics of growth in grain crop production is observed since 2003. Thus, in 2003, Ukraine produced grain in the amount of 20.2 million tons, in 2018 - 70.1 million tons that is by $24,7 \%$ more than in 2003 and by $81.14 \%$ more than in 1991 . The growth of grain crops production was achieved by increasing the crop production area and increased yields [5].

\section{Production of wheat, corn, sunflower, rape seeds and soybeans}

The main grain crops and grain legumes with the highest share in the total production are wheat, corn, sunflower, barley, soybeans, and rape.

The volume of basic grain crops harvested within the period from 2011 to 2019 is shown in Figure 3-4.

The Figure 3 shows that the largest volume of production within the period from 2011 to 2019 was wheat. While in 2011 the volume of production was 18.38 million tons, in 2019 , its value has increased by 1.6 times. The cost of wheat production shows the tendency to growth. Over the past 5 years, the cost of wheat has almost doubled. The profitability of wheat in Ukraine corresponds to the major countries producing this culture and is in average equal to $26.8 \%$. 


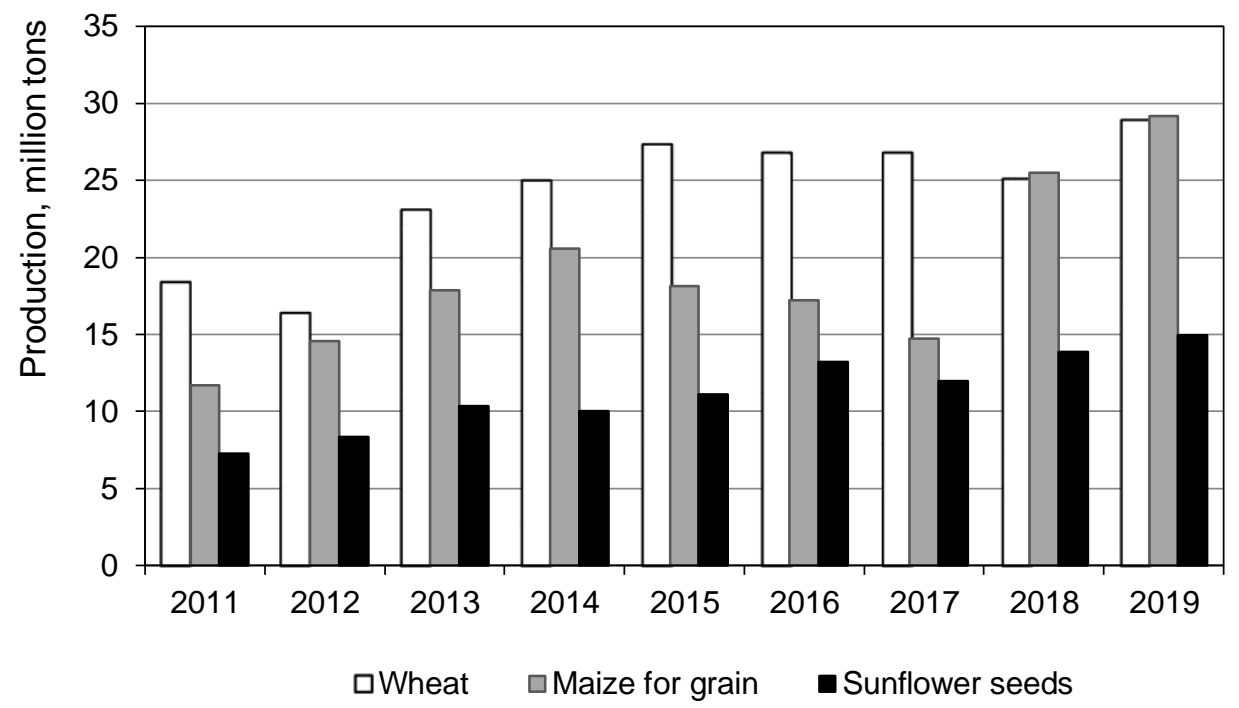

Figure 3. Production of wheat, corn, sunflower within the period from 2011 to 2019, million tons [6]

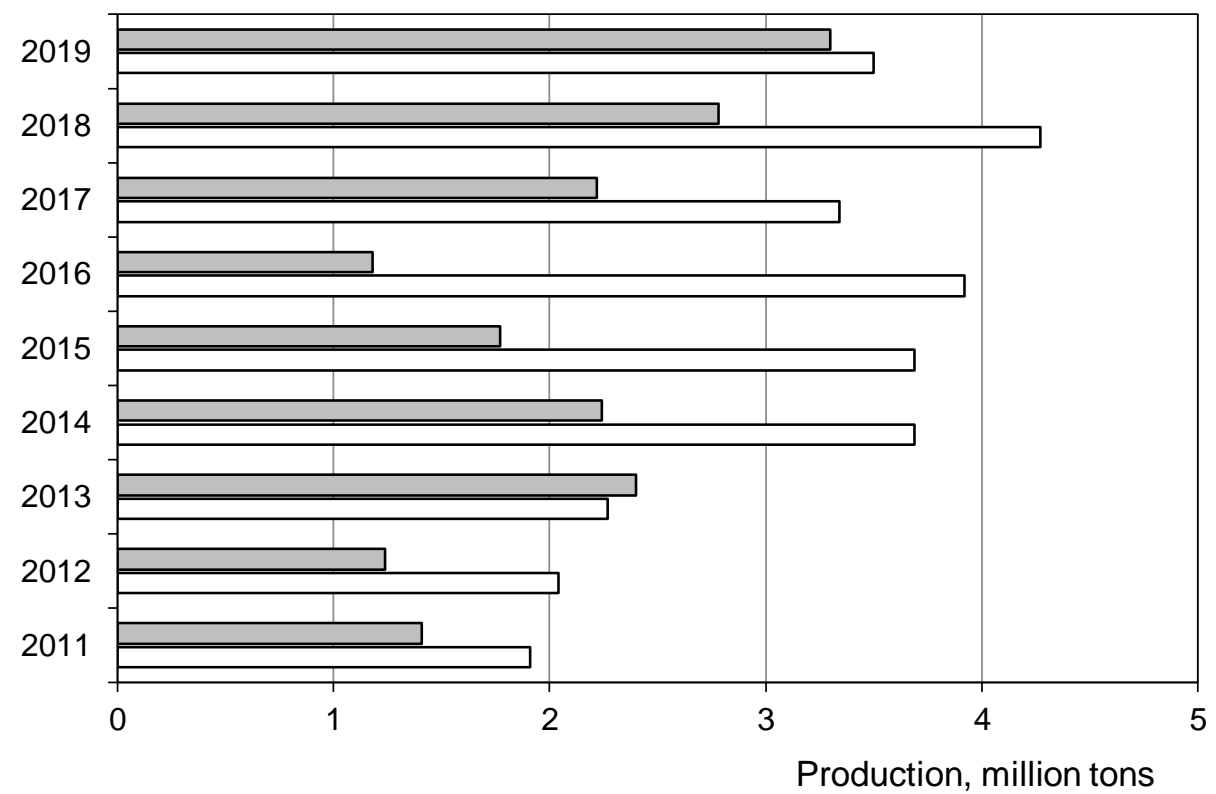

口Rapeseed $\quad$ Soya beans

Figure 4. Production of rape seeds and soybeans within the period from 2011 to 2019, million tons [6] 
Considerable positive dynamics inherent to volume of corn production within the period from 2018 to 2019 While, within the period from 2011 to 2017, the largest amount of corn production was observed in 2014, corn production in 2018 increased by 1.2 up times to 25.52 million tons as compared with this level and by 1.4 times to 29.16 million tons in 2019 due to its high yield, i. e. the amount of corn harvested per area unit. The highest corn yield indexes until 2019 were recorded in 2018, when the corn yield was 76 centners per hectare that is by $10.14 \%$ more than in 2011 and indicates the growing efficiency of corn growing [4].

Sunflower production volumes during the period from 2011 to 2019 demonstrate positive dynamics of growth. The highest yield was in 2016. (13.19 million tons), 2018 (13.88 million tons) and in 2019 (14.92 million tons).

Within the period from 2011 to 2019 , soybean production had a positive trend. The highest indexes were recorded in 2016. (105\% increase relative to 2011) and in 2018 (123.6\% increase relative to 2011) that is associated with a significant volume of harvested crops. Thus, the soybean yield in 2018 was 26.4 centners per 1 ha, and in $2016-23.6$ centners per 1 ha, and in $2019-23.2$ centners per 1 ha.

The yield of rapeseed (winter rape and colza (spring rape)) in 2018 was 27 centners per 1 ha, and in 2016 - 26.2 centners per 1 ha, and in $2019-25.9$ centners per 1 ha. Despite the fact that the rape yield in 2016 was the highest, volumes of its production during the researched period were the lowest (1.18 million tons). It is year of 2016, since which a gradual positive trend of its production is observed that indicates an extensive way of production intensification.

According to the national balance of supply and demand for grains and legumes, it should be noted that Ukraine consumes not more than 30-40 centners of grain crops and oilseeds out of 92 million tons of harvested products.

Despite the steady growth of grain production, Ukraine still has the potential for increasing the yield of grain crops. Thus, the average yield of grain crops in the USA is 82 centners per 1 ha, in China and Brazil - 52-56 centners per 1 ha, while in Ukraine in 2019 it was 48.2 centners per 1 ha.

Further growth in production of grain crops will lead to the increased deficit in storage facilities in Ukraine, the size of which is only approximately 40 million tons. Thus, $70 \%$ of the existing elevators are morally and physically obsolete. In most of them, grain is stored in bulk on the floor - under such conditions, it is very difficult to ensure quality and safety of grain. At such facilities, there are no effective transport equipment that would allow performing fast unloading and dispatch of certain types of grain.

Therefore, further increasing of production is only possible by means of increasing exports of Ukrainian grain to the world market that, in spite of tough requirements applied by it to quality and safety of Ukrainian grain, is characterized by a rapidly growing demand.

\section{Volume of foreign currency earnings from exports of grain crops by Ukraine}

Ukraine exports grain to 190 countries. The largest buyers of Ukrainian grain in 2019 was Africa, Asia, and Europe. Egypt remains the leader in the ranking of the largest importers (with a share of $14.1 \%$ ) for several years running. Significant shares in Ukrainian exports of grain crops accounted to China (9.6\%), Spain $(7.5 \%)$, Turkey $(7.4 \%)$, the Netherlands $(6.8 \%)$, Indonesia $(5.1 \%)$, Bangladesh ( $3.9 \%)$, Israel $(3.4 \%)$, Tunisia $(3.1 \%)$, and Italy $(3.1 \%)$. In aggregate, these 10 countries generate $64 \%$ of total revenues from exports of this group. The traditionally high demand for Ukrainian grain by the European Union is still preserved $-23.9 \%$ in the structure of export supplies $[3,6]$. 
The total value of exports of grain crops by Ukraine within the period from 2011 to 2019 is shown in Figure 5.

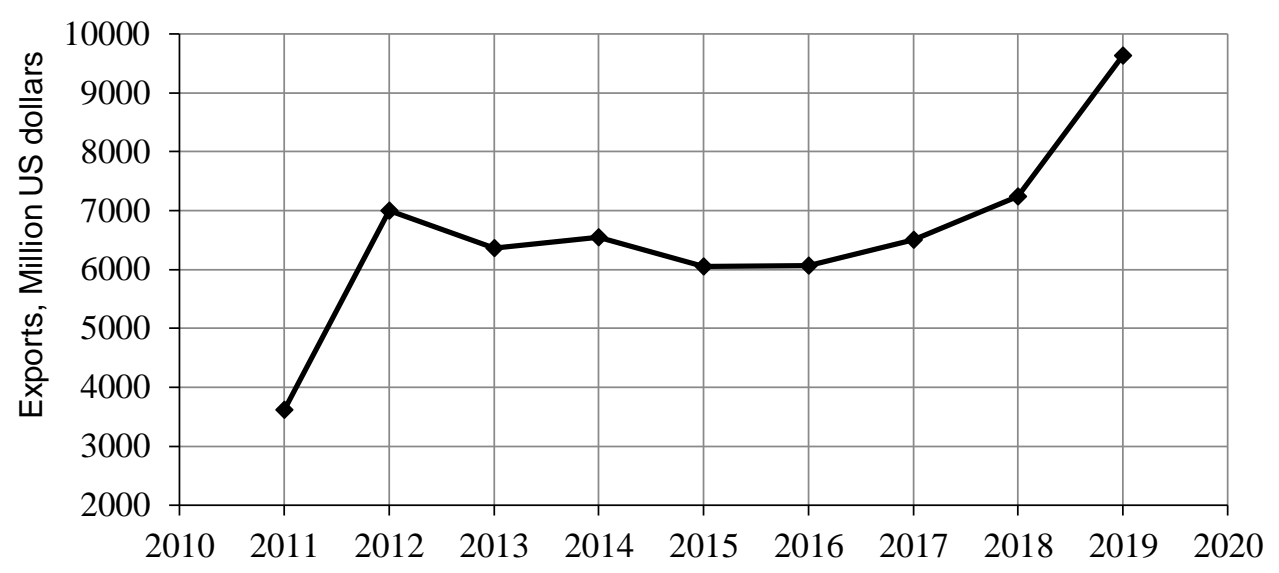

Figure 5. Exports of grain crops by Ukraine within the period from 2011 to 2019, million US dollars [6]

Thus, the volume of foreign currency earnings from exports of grain crops by Ukraine within the period from 2011 to 2019 has a positive upward trend, except for 2013 and 2015 Significant rates of growth in foreign currency earnings from the export of grain crops was observed in $2012(193.5 \%)$ and in $2019(133.1 \%)$ along with a more noticeable increase of the share of grain crops in total exports of the country (Figure 6).

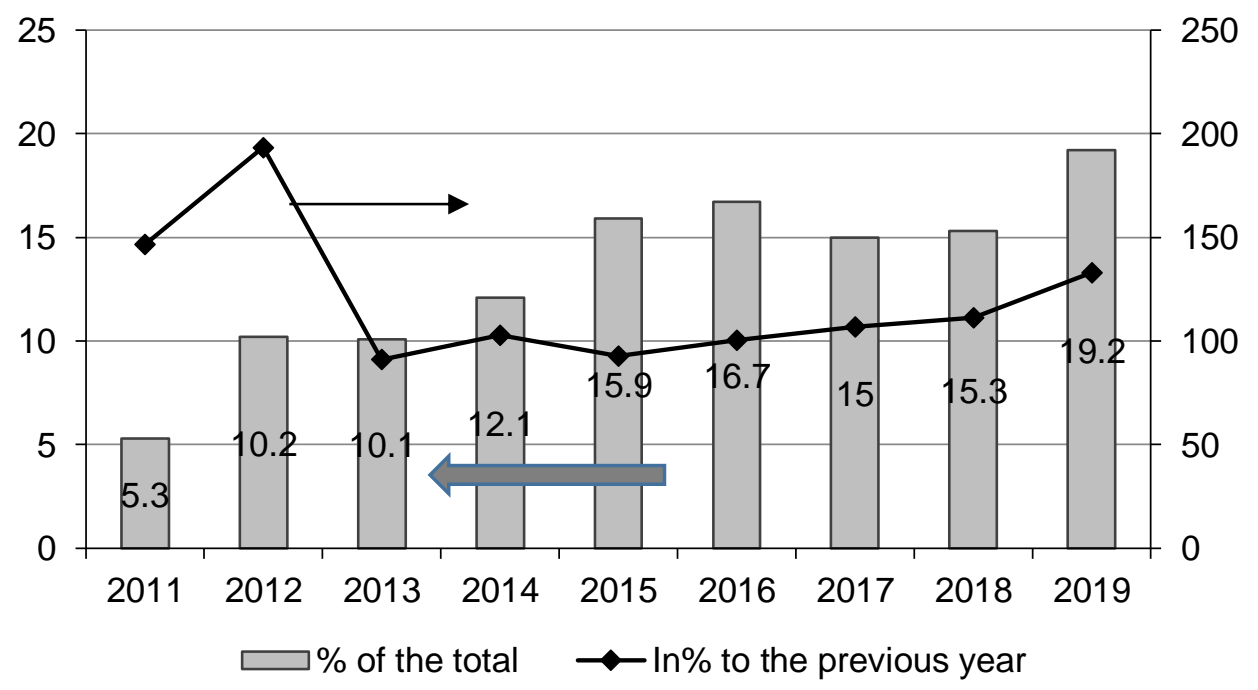

Figure 6. Share of Ukrainian exports of grain crops in the total exports and rates of growth of foreign currency earnings within the period from 2011 to 2019, \% [6] 
According to results of the 2018/2019 marketing year, Ukraine exported 50.4 million tons of grain crops, grain legumes and flour — by 10.5 million tons more than last marketing year (MP) .

Since the 2019-2020 marketing year, exports of Ukrainian wheat to EU countries increased by more than six times as compared to the same period - from 29.7 thousand tons to 188.8 thousand tons. This allowed Ukraine to become the main supplier of soft wheat to the EU with a share of $42 \%$ in total imports.

\section{Countries leading in exporting wheat}

Table 2 shows the top 10 countries-exporters of wheat.

Countries leading in exporting wheat in 2018 [2]

Table 2

\begin{tabular}{|c|l|c|c|}
\hline $\begin{array}{c}\text { Number } \\
\text { in the } \\
\text { ranking }\end{array}$ & \multicolumn{1}{|c|}{ Country } & $\begin{array}{c}\text { Exports, } \\
\text { billion US dollars }\end{array}$ & $\begin{array}{c}\text { Share in world } \\
\text { exports, \% }\end{array}$ \\
\hline 1 & Russia & 8.4 & 20.51 \\
\hline 2 & Canada & 5.7 & 13.87 \\
\hline 3 & United States of America & 5.5 & 13.27 \\
\hline 4 & France & 4.1 & 10.04 \\
\hline 5 & Australia & 3.1 & 7.54 \\
\hline 6 & Ukraine & 3.0 & 7.31 \\
\hline 7 & Argentina & 2.4 & 5.88 \\
\hline 8 & Romania & 1.2 & 2.98 \\
\hline 9 & Germany & 1.2 & 2.84 \\
\hline 10 & Kazakhstan & 0.97 & 2.35 \\
\hline
\end{tabular}

In the ranking of the 10 largest world exporters of wheat, Ukraine ranks sixth with exports for an amount of 3 billion US dollars. and a share in world exports of $7.31 \%$.

Ukraine is the third largest exporter of corn after the USA and Brazil. In the 2018-2019 marketing year, 21.4 million tons of corn were exported. The largest amount of it -11.8 million tons were purchased by European countries. Asia ranks second (6.1 million tons), countries of North Africa rank third (3.5 million tons) [3,4].

Ukrainian corn is purchased in large quantities by 12 countries that already account for $90 \%$ of exports or 18.9 million tons. Ukraine exports the largest amount of corn to the Netherlands (3.2 million tons), Spain (3.1 million tons), China (2.9 million tons), Egypt (2.4 million tons), Italy (1.8 million tons) and Iran (1.2 million tons). Germany, Turkey, Israel, Portugal, Belgium and Libya belong to twelve countries that are the major importers of Ukrainian corn [2-5].

\section{Leading exporter of corn}

The largest exporter of corn in 2018 are shown in the Table 3. 
Leading exporter of corn in 2018 [4]

\begin{tabular}{|c|l|c|c|}
\hline $\begin{array}{c}\text { Number } \\
\text { in the } \\
\text { ranking }\end{array}$ & \multicolumn{1}{|c|}{ Exporter } & $\begin{array}{c}\text { Exports, } \\
\text { million tons }\end{array}$ & $\begin{array}{c}\text { Share in national exports of } \\
\text { corn, \% }\end{array}$ \\
\hline 1 & Kernel & 2.8 & 13.5 \\
\hline 2 & COFCO Agri Ukraine & 2.3 & 11 \\
\hline 3 & ADM Trading Ukraine & 2.1 & 10 \\
\hline 4 & NIBULON & 1.6 & 8 \\
\hline 5 & $\begin{array}{l}\text { Suntrade (the major } \\
\text { subsidiary of Bunge) }\end{array}$ & 1.5 & 7.3 \\
\hline
\end{tabular}

The ten corn exporters also includes JSC "State Food and Grain Corporation of Ukraine", "Glencore Agriculture", “Ahroprosperis", "Louis Dreyfus Company Ukraine" and Black Sea Commodities, a relatively young trader on the Ukrainian market with the registered office in UAE [4].

\section{Risks and opportunities of land reform in Ukraine}

Studies have shown that, as of 1 January 2018, there are 32,214 entities engaged in growing the grain crops. $71.3 \%$ of them are farms $(22,977)$. In this case, the area, at which their share gathers in the crops, is only $15.8 \%$ that indicates that insignificant concentrations of land in farms. In addition, farms occupy $17.0 \%$ of the gross production of grain (8736 thousand tons).

The main reason for the low rate of productivity of farms is the low level of yield that is less than 15-20\% as compared with that of large manufacturers operating in the industry. The reason is poor logistics, limited access of small producers to advanced technology, lack of working capital that would provide an opportunity to purchase new plant selection varieties and appropriate means to protect them and increase yields (fertilizers, growth stimulants, etc.). However, the share of industrial enterprises with a land bank of more than 10 thousand hectares increased almost twice: from $14.2 \%$ in 2010 to $24.8 \%$ in 2016 [6]. This trend is due, firstly, to the process of consolidation of farms, including the increased levels of agricultural technology and culture cultivation ensured by increased scale. Secondly, large companies more often prefer to grow corn that, in spite of higher costs of production, has a higher yield than other crops.

The cancellation of the moratorium on sale of land brings new risks and opportunities for producers of grain crops. Thus, among the main risks of opening the land market for legal entities is massive buying of land by large agricultural holdings and fall of investment attractiveness of Ukraine. Financial risks will increase for small farmers due to the lack of the credit history and unavailability of financial instruments for the purchase of land.

The increase in prices for land after introduction of the land market will lead to an increase in rental rates that will affects both small farmers and agricultural holdings.

In addition, a long extensive development led to reduction of land banks that requires the increased efficiency in production of grain crops on smaller areas. 
A positive consequence of opening the market land to those farmers who will purchase land, on which they work: they will be able to use these lands as mortgage when taking loans in the bank [2].

\section{Conclusions}

Modern agriculture is the most dynamic sector of the national economy that is being developing actively. Ukrainian agrarian market feeds not only Ukraine with its 40 million population, but also 190 countries, and the tendency to increased production is still preserved. Our country has a huge potential for growth in production, and there is a rapidly growing demand in the world markets.

In 2019, the agricultural sector generated approximately $12-13 \%$ of Ukrainian GDP. The share of agricultural products in the total exports of Ukraine for this period was $39.8 \%$ or a record-breaking value for Ukraine of 18.8 billion US dollars. This means the receipt of foreign exchange earnings by Ukraine, stability of the hryvnia. Moreover, today, approximately three million people work for the agricultural complex. That is, if the goal of the reform lied specifically in development of the industry, then the question arises: Why do we need the land reform with such expected results? If the purpose of the reform is to attract investment, then there are barriers to development of financial and banking system of Ukraine. In this case, the farmer has to get access to credits, and hence mechanisms allowing to make loans cheaper are necessary for development of agricultural production.

\section{References}

1. (2009), Norman Borlaug: Wheat breeder who averted famine with a "Green Revolution", Available at: https://blogs.scientificamerican.com/news-blog/normanborlaug-wheat-breeder-who-av-2009-09-14.

2. (2019), U reitynhu 10 naibilshykh svitovykh eksporteriv pshenytsi Ukraina - shosta, Available at: https://dzi.gov.ua/press-centre/news/u-rejtyngu-10-najbilshyh-svitovyheks/porteriv-pshenytsi-ukrayina-shosta/

3. (2019), Ukraina u 2019 rotsi stala holovnym eksporterom pshenytsi do Yevropeiskoho soiuzu, Available at: https://www.5.ua/ekonomika/ukraina-holovnyi-eksporterpshenytsi-do-yevropeiskoho-soiuzu-u-2019-rotsi-198579.html.

4. (2019), Ukraina voshla $v$ trojku mirovyh jeksporterov kukuruzy, Available at: https://biz.liga.net/uaexport/prodovolstvie/novosti/ukraina-voshla-v-troyku-mirovyheksporterov-kukuruzy.

5. (2019), Ukraina vstanovyla novyi rekord $z$ eksportu zernovykh, Available at: https://www.epravda.com.ua/news/2019/11/4/653295/

6. (2020), Derzhavnyi komitet statystyky Ukrainy, Available at: http://www.ukrstat.gov.ua.

7. (2020), Izrailskie uchenye raskryli tajny genoma pervoj pshenicy na Zemle, Available at: $\quad$ https://mfa.gov.il/MFARUS/InnovativeIsrael/Bi\%D0\%BEtech/Pages/Israeliscientists-map-Emmer-wheat-genome.aspx.

8. (2020), O mirovyh zernovyh zapasah $i$ drugih instrumentah resheniya problemy nestabilnosti zernovyh rynkov, Available at: http://www.fao.org/3/a-i3338r.pdf

9. (2020), Rynok zerna ta produktiv pererobky, Available at: http://www.proagro.com.ua/periodical/grain/20580.html. 
10. (2020), Wheat: Science and Trade (World Agriculture Series) 1st Edition by Brett F. Carver, Available at: https://www.amazon.com/Wheat-Science-Trade-WorldAgriculture/dp/0813820243.

11. (2020), Zemelna reforma: potribni zapobizhnyky, Available at: https://m.day.kyiv.ua/uk/article/ekonomika/zemelna-reforma-potribni-zapobizhnyky.

12. Francisco Ceballos, Manuel A. Hernandez, Nicholas Minot, Miguel Robles (2017), Grain Price and Volatility Transmission from International to Domestic Markets in Developing Countries, World Development, 94, pp. 305-320.

13. Henry An, Feng Qiu, Yanan Zheng (2016), How do export controls affect price transmission and volatility spillovers in the Ukrainian wheat and flour markets?, Food Policy, pp. 142-150.

14. Hridin O. (2018), Suchasnyi stan ta tendentsii rozvytku sfer vyrobnytstva, pererobky ta realizatsii zerna: ukrainskyi ta zahalnosvitovyi kontekst, Skhidna Yevropa: ekonomika, biznes ta upravlinnia, 3 (14), pp. 60-68.

15. Kozak O., Hryshchenko O. (2016), Rozvytok zernovoi haluzi Ukrainy na suchasnomu etapi, Ekonomika APK, 1, pp. 38-47.

16. Lebid V., Pryshchepa K. (2013), Suchasnyi stan rynku zerna Ukrainy, problemy ta perspektyvy rozvytku, Ekonomichnyi visnyk Donbasu, 1, pp. 131-135.

17. Materynska O. (2017), Stratehichni zasady innovatsiinoho rozvytku vyrobnytstva zerna silskohospodarskymy pidpryiemstvamy, Ekonomika. Finansy. Menedzhment: aktualni pytannia nauky i praktyky, 5, pp. 26-34.

18. Patrick T. (2008), Cultivation of the Higher Self: William Smith Clark and Agricultural Education, Historical Journal of Massachusetts: journal. - Westfield State College, 1, pp. 36-41.

19. Shpaar D., Beme K. (2004), Reforma Obshej agrarnoj politiki v Evrosoyuze i ee posledstviya dlya FRG, APK: ekonomika, upravlenie, 7, pp. 67-76.

20. Shpykuliak O., Materynska O., Mazur H. (2014), Efektyvnist vyrobnytstva zerna silskohospodarskymy pidpryiemstvamy: teoretyko-metodolohichnyi aspekt. Ekonomika APK, 12, pp. 42-49.

21. Zakharchenko O. (2014), Suchasnyi stan ta otsinka rozvytku rynku zerna v Ukraini, Visnyk Sumskoho natsionalnoho ahrarnoho universytetu, 8, pp. 54-58. 